Review Article:

\title{
Role of Cytokines and Chemokines in the Outcome of Children With Severe Asthma: Narrative Review
}

\author{
Hamed Hatami ${ }^{1,2}$, Negar Ghaffari ${ }^{3}$, Javad Ghaffari ${ }^{3^{*}} \mathbb{D}$, Houshang Rafatpanah $^{2 *}$
}

1. Department of Immunology, School of Medicine, Mashhad University of Medical Sciences, Mashhad, Iran.

2. Immunology Research Center, Buali (Avicenna) Research Institute, Mashhad University of Medical Sciences, Mashhad, Iran.

3. Pediatric Infectious Diseases Research Center, Faculty of Medicine, Mazandaran University of Medical Sciences, Sari, Iran.

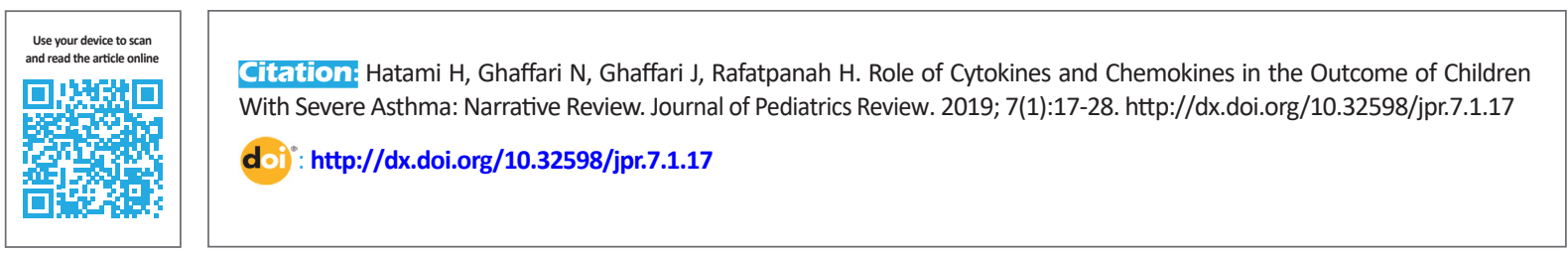

Funding: See Page 23

(c) Copyright: The Author(s)

Article info:

Received: 21 April 2017

First Revision: 30 April 2017

Accepted: 24 February 2018

Published: 01 January 2019

Keywords:

Severe asthma,

Cytokines, Chemotactic

\begin{abstract}
A B S T R A C T
Context: Asthma, characterized by airway inflammation, is a common chronic disease of childhood. Cytokines and chemokines could be used in the diagnosis, treatment, and management of asthma severity in children. In this review, we have explained the application of cytokines and chemokines as biomarkers in pediatric asthma.
\end{abstract}

Evidence Acquisition: All related articles were separately searched by two researchers using the following keywords in PubMed, Scopus, and Embase databases: Cytokine biomarkers, chemokines biomarkers, and children asthma. Articles published from 2000 to 2017 were investigated in the research, and 28 articles were included in the final analysis for this review.

Results: About cytokines, serum Interleukin 4 (IL-4) level is a marker of the presence of asthma, and IL-13 is a key cytokine involved in the manifestation of asthma symptoms. High IL-13 concentration and number of IL-13+ cells in the bronchial submucosa specimens are characteristic of severe asthma. Serum IL-5 concentration 3.1 times in children with severe asthma. IL-17 is involved in airway obstruction. IFN- $\gamma$ gene polymorphism $(+874 \mathrm{~A} / \mathrm{T})$ in children elevates susceptibility to asthma. TGFB1 polymorphisms are considered as indicators of asthma severity. IL-26 plays an important role in asthma severity. IP-10 may be a useful inflammatory marker of asthma severity. High periostin level has been identified in pediatric asthma. PDGF level, which is high in asthma patients, plays an important role in bronchial fibrosis. About chemokines, plasma TARC concentration may be a useful biomarker of airway inflammation and asthma severity in children. Studies have supported the association between high serum RANTES levels and severe airway obstruction in children. CXCR4 levels are high in pediatric asthma and are associated with disease severity.

Conclusions: A wide range of cytokines and chemokines may play important roles in asthma severity in pediatric patients. Therefore, several studies have recommended the use of multiple molecular biomarkers, such as cytokines, for determining asthma severity in children.

\section{* Corresponding Author:}

Address: Immunology Research Center, Buali (Avicenna) Research Institute, Mashhad University of Medical Sciences, Mashhad, Iran. Department of Pediatric Immunology and Allergy, Bou-Ali Sina Hospital, Pasdaran Blv., Sari, Iran.

Tel: +98 (11) 33342331

E-mail: rafatpanahh@mums.ac.ir; javadneg@yahoo.com 


\section{Context}

A

sthma is a complex disorder and one of the most common chronic diseases of childhood it is characterized by reversible airflow obstruction, bronchial hyperresponsiveness, mucus hypersecretion, inflammatory cell migration into the airways, and structural airway remodeling (1). Over the last decade, the worldwide incidence of asthma in children has been increasing (2).

Although the clinical features of asthma in children have been well described, the pathophysiological characteristics of asthma are less understood, and therapeutic strategies have mostly focused on asthma control. Inflammatory responses in asthma are driven by immune mechanisms involving cytokines, which are novel mediators that integrate signals between various immune cells (3) and thus play important roles in the pathogenesis of asthma. The National Institutes of Health defines a biomarker as "a characteristic that is objectively measured and evaluated as an indicator of normal biological processes, pathogenic processes, or pharmacologic responses to a therapeutic intervention" (4). Therefore, knowledge about the actions of cytokines will provide a novel clinical context to develop novel biomarkers and therapies for various asthma subgroups in pediatric patients. The molecular phenotypes and endotypes of asthma differ between children and adult $(5,6)$. Unlike adults, mild to moderate asthma in most children is characterized by eosinophilic and neutrophilic airway inflammation (7). Based on pathogenesis, the degree of airway obstruction, and responses to medications, pediatric asthma can be divided into intermittent, mild, moderate, and severe stages $(8,9)$.

Clinically, asthma severity is associated with lung function and airway responsiveness, but underlying pathogenesis of asthma are not clear exactly (10). Thus, the characterization of cytokines might play an important role in the development of diagnostic markers for and treatment and management of pediatric asthma severity (8). This study further supports the use of cytokines as biomarkers, with particular emphasis on noninvasive sampling and cytokine assessment, to evaluate pediatric asthma severity. Tissue-specific diagnostic methods, such as bronchoalveolar lavage (BAL) and bronchoscopy, are also useful to detect airway inflammation and airway remodeling in asthma patients $(11,12)$. However, the invasiveness of these methods decreases their clinical utility in children. Therefore, the availability of noninvasive sampling procedures to examine and manage asthma in pediatric patients is particularly essential. Many noninvasive methods, such as peripheral blood/serum collection, Exhaled Breath Condensate (EBC) collection, and sputum induction, are available for assessing pediatric asth- ma (13). This review aims to develop knowledge in the field of pediatric asthma biomarkers, with a focus on cytokines and chemokines in blood/serum, EBC, and induced sputum.

\section{Evidence Acquisition}

All related articles were separately searched by two researchers. PubMed, Scopus, and Embase databases were searched using the following keywords: cytokine biomarkers, chemokines biomarkers, and children asthma. Articles published during 2000-2017 were included in the search. The primary search rendered 128 related articles, which were narrowed down to 28 suitable articles for inclusion in the final analysis for this review.

\section{Results}

Cytokines are small glycoproteins that coordinate an effective immune response among various immune cells (14). A wide range of cytokines and chemokines play important roles in asthma severity in pediatric patients. These include interleukin (IL)-4, IL-5, IL-13, IL-17, IL-26, transforming growth factor beta (TGF- $\beta$ ), interferon gamma (IFN- $\gamma$ ), and novel mediators such as IFN- $\gamma$-inducible protein 10 (IP10; CXCL10), periostin, and proangiogenic factors.

\subsection{IL-4}

IL-4 is a key cytokine produced by CD4 ${ }^{+}$Th2 cells (15), mast cells, and basophils. It induces the production of IgE and expression of major histocompatibility complex class-II molecules, B7, CD40, and surface IgM on B cells, thereby enhancing their antigen-presenting capacity (14). It is the key cytokine involved in the pathogenesis of allergic diseases (16) and is implicated in airway remodeling and stimulation of mucus-producing cells (17). Its overexpression in the lungs induces eosinophilic inflammation without airway hyperreactivity (18); Therefore, demonstrating its involvement in asthma had been difficult. An increased IL-4/IFN- $\gamma$ ratio in the EBC, predominantly accompanied by an increased number of Th2 cells in the airway, is associated with pediatric asthma severity (19). IL-4 is a useful biomarker for detecting severe asthma along with other inflammatory markers, such as INF- $\gamma$, IL-5, and Granulocyte-Macrophage Colony-Stimulating Factor (GM-CSF) $(20,21)$. IL-4 levels are low in BAL Fluids (BALF) of children using inhaled corticosteroids (11) but do not differ between intermittent, mild, moderate, and severe persistent asthma (22).

\subsection{IL-13}

The functional and structural characterization of IL-13 are similar to that of IL-4 (14). Their receptors (IL-4R $\alpha$ ) 
IL-13R $\alpha 1$ ) are present on activated B and T cells, macrophages, mast cells, fibroblasts, epithelial cells, muscle cells, and hematopoietic progenitor cells (23). IL-13 signaling influences the Th1/Th2 balance via the STAT6 pathway and is involved in asthma. High levels of IL-13 are secreted by Th2 cells in asthma patients (24). IL-13 induces eosinophil infiltration, goblet cell hyperplasia, mucus secretion, contractility of airway smooth muscle cells, and IgE production from B cells. Serum IL-13 levels increase in pediatric asthma, supporting the positive correlation between severe asthma and high IgE levels (18).

Another study has demonstrated that the percentage of CD4+/IL-13+ T cells is higher than that of CD4+/IL-4+ T cells in the peripheral blood of children with severe asthma, suggesting that IL-13 is an important cytokine associated with asthma symptoms and is the key inflammatory cytokine in the Th2-driven immunopathology involved in asthma (3). In addition, IL-13 expression in bronchial submucosa specimens, BALF, induced sputum, and serum increases in adult asthma patients (21). IL-13 overexpression in BALF is reportedly the best marker of pediatric asthma (25). High sputum IL-13 concentration and number of IL-13+ cells in the bronchial submucosa specimens are characteristic of severe asthma (26).

\subsection{IL-5}

IL-5 is produced by eosinophils, mast cells, Natural Killer (NK) cells, epithelial cells, CD4+ and CD8+ T cells, and nonhematopoietic cells, such as epithelial cells. IL-5 Receptor (IL-5R) is expressed on eosinophils, basophils, and B lymphocytes. IL-5 plays a key role in the development, survival, and chemoattraction of eosinophils (14). It is secreted by T lymphocytes in asthmatic airways and increases the sputum eosinophil count in asthma patients. Blocking of IL-5 with anti-IL-5 (mepolizumab) in asthma significantly reduces eosinophilic inflammation and airway hyperresponsiveness (27-29). Plasma IL-5 levels decrease during steroid therapy in severe pediatric asthma (30). High serum IL-5 and IgE levels have been documented in children with severe asthma (16).

\subsection{IL-17}

IL-17 is a CD4+ T cell (Th17)-derived cytokine; its release is induced by IL-23 (31). IL-17A is the main cytokine produced by Th17 cells. It stimulates epithelial, endothelial, and fibroblastic cells to secrete proinflammatory cytokines, such as IL-8, IL-6, GM-CSF, IL-1 $\beta$, TGF- $\beta$, and tumor necrosis factor $\alpha$ (14). Various samples (sputum, BALF, bronchial biopsies, and plasma) from children with asthma have shown the involvement of high IL-17 levels in airway obstruction. Blocking of IL-17 in asthma leads to a significant reduction in airway inflammation $(3,32)$. The IL-17 expression is significantly elevated in the serum of children with severe asthma; therefore, serum IL-17 concentration has been described as an independent marker of inflammation in severe asthma and its measurement provides a noninvasive method for evaluating asthma severity (19). II-17 may also be involved in steroid hyperresponsiveness (33). Moreover, another study has reported that IL-17 expression decreases in patients using corticosteroids (34).

\subsection{IFN- -}

IFN- $\gamma$ is a Th1 cytokine that inhibits the production of Th2 cytokines, such as IL-4, IL-5, and IL-13, and decreases the production of $\operatorname{IgE}(14,20,35)$. Children with asthma exhibit significantly low IFN- $p$ levels. High serum IFN- $\gamma$ levels are correlated with reduced blood eosinophil counts and total IgE levels in such children (20). IFN- $\gamma$ gene polymorphism $(+874)$ increases the susceptibility to asthma in children (18). Elevated serum IFN- $\gamma$ levels in BALF and during Respiratory Syncytial Virus (RSV) infection have been reported in pediatric asthma $(11,32)$. Thus, the hypothesis that only increased Th2 cytokine levels are involved in asthma is not correct, and Th1 cytokines may also have inflammatory responses in pediatric asthma $(21,28)$.

\subsection{IL-6 and IL-8}

In our previous study, serum IL-6 and IL-8 levels did not differ between patients with mild and severe asthma (36), indicating that these cytokines could not predict asthma severity.

\subsection{TGF- $\beta$}

TGF- $\beta$ is a cytokine produced by many cells, including eosinophils, neutrophils, mast cells, structural cells such as epithelial and endothelial cells, airway smooth muscle cells and fibroblasts $(35,37)$. It plays a key role in pediatric asthma severity and the degree of subepithelial fibrosis (38). TGF- $\beta$, together with Platelet-Derived Growth Factor (PDGF), is considered as a marker of airway remodeling in asthma. It modulates the action of T cells during inflammation. One study that evaluated the key role of Treg cells in asthma suppression has found that blood Treg cell counts and the level of its transcription factor FOXP3 are low and TGF- $\beta$ gene expression is high in pediatric asthma (34). Alternatively, it is speculated that high TGF- $\beta$ levels can control a feedback mechanism to maintain immune response, but the source of this feedback loop is unclear (39). TGF- $\beta$ levels increase in Bronchoalveolar Lavage Fluid (BALF) in pediatric asthma. Another study has found that TGF- $\beta$ levels are positively correlated with IL-13 levels in severe 
pediatric asthma (40). Increased serum TGF- $\beta$ levels in children with severe asthma reportedly cause significant reductions in inflammatory responses despite steroid inhalation therapy (41). Another study involving bronchial biopsy specimens obtained from children with severe asthma has demonstrated significantly high TGF- $\beta$ expression (34). TGFB1 polymorphisms are considered as useful indicators of asthma severity (airway responsiveness and disease exacerbations) in children (42) (Table 1).

\subsection{IL-26}

IL-26 is a member of the IL-10 cytokine family and is expressed by Th17 cells and other leukocytes. It has both pro- and anti-inflammatory properties and contributes to neutrophil mobilization in the airways. High sputum IL-26 levels are found in pediatric asthma, indicating that IL-26 plays an important role in asthma severity. Thus, IL-26 has been suggested as a novel biomarker of asthma severity in children (43).

\subsection{IP-10}

IP-10, known as CXCL-10, is a CXC chemokine produced by activated $T$ cells. Through its interaction with CXCR3+, a ligand highly expressed on activated Th1 cells, IP-10 attracts inflammatory cells to the inflammation site. Viral infections in children promote Th1 inflammation. Type I and II IFNs stimulate IP-10 expression by T cells in the bronchial epithelia as a chemoattractant leading to severe acute asthma. Studies have shown elevated serum IP-10 levels in virus-induced pediatric asthma (44). IP-10 levels are significantly elevated in acute pediatric asthma compared with that in stable pediatric asthma, especially in the BALF of children with asthma. In addition, their levels are positively correlated with the severity of airway obstruction in pediatric asthma. Thus, IP-10 may be a useful inflammatory marker of asthma severity (45).

\subsection{Periostin}

Periostin is the extracellular matrix protein secreted by osteoblasts and mesenchymal cells. POSTN gene expression increases in the airway epithelium of children with asthma. The Th2 cytokines IL-4 and IL-13 induce periostin production in bronchial epithelial cells in asthma (46), which is secreted directly into the blood vessels. Increased periostin levels in the blood of children with asthma stimulate collagen synthesis, fibrillogenesis, and TGF- $\beta$ activation. POSTN gene expression decreases in pediatric asthma after treatment with corticosteroids (8). Serum periostin level is a more useful biomarker of pediatric asthma than blood eosinophil count and IgE level. Therefore, a useful systemic biomarker of eosinophilia in the airway lumen and tissue (46). In growing children, periostin is released from the bones, but higher periostin levels have been identified in asthmatic children than in healthy children $(1,8)$. More studies are needed on the use of periostin level as a biomarker in clinical practice. Nonetheless, serum periostin level is considered as an independent predictor of increased asthma severity (1).

\subsection{Angiogenic factors}

Asthma severity has been highly correlated with airway remodeling in the airway tract; these changes include extracellular matrix enhancement, smooth muscle cell hyperplasia, and neovascularization (47). Proangiogenic factors play important roles in asthma progression. Several angiogenesis regulators, including thrombospondin-1, matrix metalloproteinase-9 and its inhibitor TIMP-1, dipeptidyl peptidase IV, and PDGF-AA, are involved in the regulation of airway remodeling and angiogenesis in pediatric asthma. Elevated PDGF-AA levels are observed in the EBC of asthmatic children with severe airflow limitation. PDGF plays an important role in bronchial fibrosis $(47,48)$.

\subsection{Chemokines}

Chemokines are a group of chemotactic cytokines that regulate cell trafficking. They can be classified into four subclasses, namely CXC, CC, C, and CX3C, depending on the spacing of conserved cysteine residues (49). Certain regulatory factors, such as CXCR4, CCR3, RANTES, and Thymus and ActivationRegulated Chemokine (TARC), that are categorized as chemokines play key roles in pediatric asthma severity.

\subsection{TARC}

TARC is a novel chemokine. The TARC-encoding gene is located on chromosome 16 (16q13) and expresses a 71-amino-acid-long basic protein with a molecular weight of 8 kDa (50). It acts on the chemokine receptor CCR4, which is expressed on peripheral blood mononuclear cells and human T lymphocytes (49). High serum and sputum levels of CCR4+ CD4+ cells and TARC accompanied by high total IgE concentration in the plasma of children with asthma have been documented (50). Another study utilizing BALF specimens obtained from children with severe asthma has demonstrated high TARC levels. However, because BALF analysis is an invasive method, a noninvasive method, such as sputum analysis, should be considered in children (51). Plasma TARC concentration may be a useful biomarker for airway inflammation and asthma severity in children before the clinical presentation (50). 


\subsection{RANTES}

RANTES (regulated upon activation, normal T-cell expressed and secreted), also known as chemokine ligand 5 (CCL5), is a CC chemokine produced by T lymphocytes, fibroblasts, eosinophils, endothelial cells, platelets, and other cells and has been suggested as the key mediator in asthma (52). CCL5 attracts several types of inflammatory cells, including eosinophils, monocytes, and Th cells, to inflammation site, and exhaled RANTES levels are associated with asthma severity and serum IgE levels (19). In one study, exhaled RANTES levels were found to be higher in children with mild to severe asthma than in healthy controls (19). RANTES has also been implicated in airway inflammation responses because of its ability to attract and stimulate several types of inflammatory cells $(19,45)$. A study that evaluated the important role of RANTES in asthma development has found that increased serum RANTES levels in pediatric asthma may enhance Th2 lymphocyte migration into the airway (45). Serum RANTES level may be a useful noninvasive marker of airway inflammation and may play a significant role in monitoring asthma severity (52). Notably, RANTES has also been introduced as an important marker for differentiating between moderate and severe pediatric asthma. Studies showing increased RANTES levels in the BALF of asthma patients have implicated RANTES in eosinophil chemoattractant activity, which is blocked in the presence of anti-RANTES antibody. In one study, among the cytokines and chemokines, namely growth-related oncogene (CXCL1), RANTES, IL-12, IL-6, IFN- $\gamma$, and IL-10, that were examined in the BALF and Alveolar Macrophage (AM) lysate of children with asthma, RANTES was found to be a potential factor for distinguishing between severe and moderate pediatric asthma. However, analyses of BALF and AM lysate are invasiveness methods and therefore unsuitable for children (25).

A significant correlation has been found between the CCL5 -28C/G polymorphism and pediatric asthma severity (53). Reportedly, the RANTES 403G/A polymorphism enhances RANTES transcriptional activity and gene expression, supporting the association between high serum RANTES levels and severe airway obstruction in children (32).

\subsection{CXCR4}

The Th2 cell subset expresses CCR3, CCR4, CCR8, and CXCR4 receptors. Among these, CXCR4 has been associated with marked attenuation of asthma. CXCR4 and its ligand SDF-1 have been considered as more effective markers of migratory response in asthma than the CCR3/ eotaxin system. In children with bronchial asthma, lymphocytes tend to overexpress CXCR4, which is associated with asthma severity (54). CXCR4 plays a crucial role in airway inflammation and promotes the differentiation of B cells into IgE-secretory plasma cells as well as Th2 cell infiltration, leading to asthma $(51,54)$. The MCP-4/CCR3 interaction acts as a chemoattractant for eosinophils in asthma and has been related to asthma exacerbation (55); consequently, eosinophil counts in the sputum and serum of children with asthma are significantly high. A recent trial of inhaled corticosteroids therapy in pediatric asthma has

Table 1. Association of selected molecular polymorphisms with asthma severity in children

\begin{tabular}{|c|c|c|c|c|c|}
\hline Marker & SNP & Alleles & Function & Asthmatic Population & References \\
\hline RANTES & $\begin{array}{c}-28 \\
(\mathrm{rs} 2280788)\end{array}$ & $C>G$ & Higher CCL5 expression & Children(meta-analysis) & {$[53]$} \\
\hline $\mathrm{INF}_{-\gamma}$ & +874 & $\mathrm{~T}>\mathrm{A}$ & Decrease INF- ${ }_{-\gamma}$ expression & Children from Saudi Arabia & {$[18]$} \\
\hline IL4 & $\begin{array}{c}-589 \\
\text { (rs 2243250) }\end{array}$ & $\mathrm{C}>\mathrm{T}$ & Increased IL-4 & & \\
\hline IL13 & $\begin{array}{c}-1112 \\
\text { (rs 1800925) }\end{array}$ & $\mathrm{C}>\mathrm{T}$ & Elevated serum IgE levels & & \\
\hline IL4R $\alpha$ & $\begin{array}{c}148 \\
\text { (rs 1805010) }\end{array}$ & $A>G$ & $\begin{array}{l}\text { Higher IgE,IL-4 and stat6 } \\
\text { expression }\end{array}$ & German children (age 9 to 11 years) & {$[15]$} \\
\hline STAT6 & $\begin{array}{l}2829 \\
\text { (rs 324011) }\end{array}$ & $C>T$ & Elevated serum IgE levels & & \\
\hline TGF $\beta 1$ & $\begin{array}{c}-509 \\
(\mathrm{rs} 1800469)\end{array}$ & $\mathrm{C}>\mathrm{T}$ & Higher TGF $\beta 1$ expression & $\begin{array}{c}\text { Children } 6 \text { to } 14 \text { years of age in Costa } \\
\text { Rica cohort }\end{array}$ & {$[42]$} \\
\hline TLR2 & -16934 & $\mathrm{~T}>\mathrm{A}$ & $\begin{array}{l}\text { Modify interaction with micro- } \\
\text { bial molecules }\end{array}$ & $\begin{array}{c}\text { Children from rural communities in } \\
\text { Austria and Germany }\end{array}$ & {$[57]$} \\
\hline
\end{tabular}


shown that corticosteroids decrease Th2 cell activation and MCP-4 expression (56).

The mechanisms of airway inflammation in children are unknown. The mechanisms underlying asthma may differ between children and adults $(6,7,12,57,58)$. Cytokines play an important role in coordinating mechanisms involved in asthma and are directly associated with asthma phenotypes. The genetic polymorphisms and profiles of cytokines and chemokines are key factors affecting the airway inflammatory processes. No relationship has yet been established between inflammatory markers (serum eosinophil count, exhaled nitric oxide, and serum eosino- phil cationic protein) and pediatric asthma severity (10 59-61). Therefore, further studies are required on the use of multiple molecular biomarkers, such as cytokines, for differentiating between asthma severities in children (25).

Eosinophil and mast cell cytokines (IL-4, IL-5 and eotaxin) involved in allergic sensitization in children are important for the pathogenesis of severe pediatric asthma in most cases and play key roles in airway remodeling (62). Airway remodeling is characterized by the thickening of reticular basement membrane, subepithelial fibrosis, and airway smooth muscle hyperplasia $(34,62)$.

Table 2. Description of multiple cytokine biomarkers, which increase in noninvasive samples (sputum, exhaled breath condensate, and blood), for assessing pediatric asthma severity

\begin{tabular}{|c|c|c|c|c|}
\hline Biomarker & Sample & Function & Asthmatic Children Age & References \\
\hline TARC & Serum & $\begin{array}{l}\text { Increase the trafficking of Th2 lymphocytes into sites of } \\
\text { airway inflammation and total IgE level }\end{array}$ & 6-15 Years old & {$[50]$} \\
\hline TGF- $\beta$ & Peripheral blood & Remodeling process and modulate the action of T cells & 2-6 Years old & [39] \\
\hline \multirow{2}{*}{ RANTES } & Serum & $\begin{array}{c}\text { Enhancement of Th2 lymphocyte migration into the } \\
\text { airway }\end{array}$ & 4.5-16 Years old & [45] \\
\hline & EBC & Increase the eosinophils migration and IgE level & $6-18$ Years old & {$[19]$} \\
\hline PERIOSTIN & Serum & Stimulates collagen synthesis and TGF- $\beta$ activation & 6-15 Years old & [8] \\
\hline IL-26 & Sputum & Mobilization of neutrophils in the airways & 13.7 Years median age & [43] \\
\hline \multirow{2}{*}{ IL-13 } & Serum & $\begin{array}{l}\text { Enhance contractility of airway smooth muscle cells and } \\
\qquad \text { IgE level }\end{array}$ & 10.12 Years median age & [18] \\
\hline & Peripheral blood & Inducing IgE expression & 9.02 Years median age & {$[22]$} \\
\hline IL-5 & Serum & Survival and chemoattraction of eosinophils & $\begin{array}{l}\text { 13.5 Years median age } \\
12.2 \text { Years median age }\end{array}$ & $\begin{array}{l}{[21]} \\
{[16]}\end{array}$ \\
\hline \multirow[t]{2}{*}{$\mathrm{IL}-4$} & EBC & Promote eosinophilic inflammation and Th2 response & $\begin{array}{l}6-18 \text { Years of age } \\
2-18 \text { Years of age }\end{array}$ & $\begin{array}{l}{[19]} \\
{[17]}\end{array}$ \\
\hline & Serum & Increase the eosinophils inflammation and IgE level & 12.2 Years median age & [16] \\
\hline CXCR-4 & Peripheral blood & $\begin{array}{l}\text { Enhancement of Th2 lymphocyte migration into the } \\
\text { airway and Inducing IgE expression }\end{array}$ & 5-12 Years old & [54] \\
\hline CCR3 & Sputum & Eosinophil chemotactic effects & 10.72 Years median age & [56] \\
\hline IL-17 & Serum & $\begin{array}{c}\text { Induce expression of pro-inflammatory cytokines and } \\
\text { neutrophils recruitment }\end{array}$ & Under the age of 5 year & [33] \\
\hline IP-10 & Serum & Attract inflammatory cells (Th-1) into site of inflammation & $\begin{array}{l}\text { Significantly under the age } \\
\text { of } 3 \text { year }\end{array}$ & [44] \\
\hline INF- $-\gamma$ & Serum & Inflammatory effects and Th1/Th2 imbalance & $\begin{array}{c}\text { 13.5 Years median age } \\
\text { 10.12 Years median age } \\
2-18 \text { Years of age }\end{array}$ & $\begin{array}{l}{[21]} \\
{[18]} \\
{[17]}\end{array}$ \\
\hline $\begin{array}{l}\text { Angiogenic } \\
\text { factors }\end{array}$ & EBC & $\begin{array}{l}\text { Functional and structural changes in respiratory tract } \\
\text { (remodeling) }\end{array}$ & $\begin{array}{l}14 \text { Years median age } \\
12.7 \text { Years median age }\end{array}$ & $\begin{array}{l}{[47]} \\
{[48]}\end{array}$ \\
\hline
\end{tabular}


Several studies have shown the usefulness of some cytokines, such as IL-4, in only identifying asthma and that they are not helpful in distinguishing between mild and severe asthma phenotypes $(18,22)$. IL-26 has been described as a biomarker of pediatric asthma severity without Th2mediated eosinophilic airway inflammation. However, the relationship between IL-26 and low sensitivity to inhaled steroids is unknown (43). TGF- $\beta$ contributes to the development of severe airway inflammation in children and increased collagen (types I and III) synthesis compared with IL-11 and IL-17 (34). High TGF- $\beta$ expression leads to airway remodeling, whereas decreased TGF- $\beta$ expression leads to anti-fibrotic effects (42).

Several other biomarkers, such as vitamin D, are involved in the severity, pathogenesis, and immunopathology of pediatric asthma $(63,64)$. Vitamin D plays an important role in pediatric asthma severity and airway remodeling by inducing the expression of CD23/21 (low-affinity IgE receptor on B lymphocytes) and FoxP3 factor (key translation factor in Treg lymphocytes) $(39,65)$. Another study has shown that individuals with FOXP3 gene polymorphism could be susceptibility to allergic diseases, such as allergic rhinitis (66).

Stimulation of the highly sensitive receptors of innate cells known as toll-like receptors (TLRs) promotes cytokine expression and inflammatory processes $(67,68)$. TLR stimulation is known to promote the involvement of innate immune cells (eosinophils, basophils, and NK cells) in severe Th2-associated responses involved in pediatric asthma (57). Therefore, further investigations are required to obtain new insights into the role of innate immune responses in cytokine expression involved in pediatric asthma.

Cytokines synthesis in response to viral infection (RSV infection) in children is associated with asthma severity. Reportedly, RSV infection stimulates the secretion of several cytokines, including IL-4, IL-5, IL-13, IL-17, IL-6, IL-8, IFN- $\gamma$, CCL5, CCL11, and CXCL10, which are involved in severe asthma responses $(32,44)$. One study has suggested the involvement of Th1 proinflammatory cytokines, such as IFN- $\gamma$ and IL-12, in the pathogenesis of pediatric asthma, indicating that in some cases, pediatric asthma is not simply a Th2-driven response (11).

Invasive methods requiring repeated sampling are not suitable for asthma monitoring (69). BAL and endobronchial biopsy are the reference standards for distinguishing the extent of eosinophilic airway inflammation (70). These approaches have been used to measure airway inflammatory molecules, such as cytokines, in many studies but are invasive and expensive. Therefore, noninvasive techniques are needed for evaluating biomarkers of airway inflammation in pediatric asthma patients (Table 2).

Noninvasive methods, such as analyses of induced sputum and EBC samples, are clinically useful in evaluating asthma $(13,69,71,72)$ and can be performed repeatedly. However, EBC and sputum samples require appropriate standardization $(1,73)$. Currently, the measurement of fractional exhaled nitric oxide is the only validated minimally invasive method for assessing asthma-related eosinophilic inflammation in clinical practice $(13,74)$. However, its accuracy to distinguish asthma severity between children with different phenotypes and endotypes remains unclear, and it has various shortcomings; therefore, its results should be confirmed using other useful biomarkers, such as cytokines, in sputum, EBC, and blood/serum, which have been described for assessing asthma severity in children (75).

\section{Conclusions}

A wide range of cytokines and Chemokines may be important in disease severity in pediatric. However, Studies recommend the use of multiple molecular biomarkers such as cytokines for differentiation of asthma severity in children.

\section{Ethical Considerations}

Funding

This research did not receive any specific grant from funding agencies in the public, commercial, or not-forprofit sectors.

\section{Conflict of interest}

All authors certify that this manuscript has neither been published in whole nor in part nor being considered for publication elsewhere. The authors declare no conflict of interest.

\section{References}

1. Moschino L, Zanconato S, Bozzetto S, Baraldi E, Carraro S. Childhood asthma biomarkers: Present knowledge and future steps. Paediatric Respiratory Reviews. 2015; 16(4):205-12. [DOI:10.1016/j.prrv.2015.05.001] [PMID]

2. Ghaffari J, Aarabi M. The prevalence of pediatric asthma in the Islamic Republic of Iran: A systematic review and meta-analysis. Journal of Paediatrics Review. 2013 1(1):2-11. 
3. Gibeon D, Menzies Gow AN. Targeting interleukins to treat severe asthma. Expert Review of Respiratory Medicine. 2012; 6(4):423-39. [DOI:10.1586/ers.12.38] [PMID]

4. Zedan MM, Osman AM, Laimon WN, Abo-elkheir NY, Zak A. Airway inflammatory biomarker:Could it tailor the right medications for the right asthmatic patient. Iranian Journal of Immunology. 2016; 13(2):70-88. [PMID]

5. Fainardi V, Saglani S. The need to differentiate between adults and children when treating severe asthma. Expert Review of Respiratory Medicine. 2015; 9(4):419-28. [DOI: 10.1586/17476348.2015.1068693] [PMID]

6. Bush A, Menzies-Gow A. Phenotypic differences between pediatric and adult asthma. Proceedings of the American Thoracic Society. 2009; 6(8):712-9. [DOI:10.1513/ pats.200906-046DP] [PMID]

7. Guilbert TW, Bacharier LB, Fitzpatrick AM. Severe asthma in children. The Journal of Allergy and Clinical Immunology In Practice. 2014; 2(5):489-500. [DOI:10.1016/j. jaip.2014.06.022] [PMID] [PMCID]

8. Federico MJ, Hoch HE, Anderson WC, Spahn JD, Szefler SJ. Asthma management for children. Advances in Pediatrics. 2016; 63:103-26. [DOI:10.1016/j.yapd.2016.04.010] [PMID]

9. Chelbi H, Ghadiri A, Lachheb J, Ghandil P, Hamzaoui K, Hamzaoui $A$, et al. A polymorphism in the CCL2 chemokine gene is associated with asthma risk: A case-control and a family study in Tunisia. Genes and Immunity. 2008 9:57581. [DOI:10.1038/gene.2008.50] [PMID]

10. Wilson N, James A, Uasuf C, Payne DN, Hablas H, Agrofioti $C$, et al. Asthma severity and infammation markers in children. Asthma severity and infammation markers in children. 2001; 12:125-32. [DOI:10.1034/j.13993038.2001.012003125.x] [PMID]

11. Brown V, Warke TJ, Shields MD, Ennis M. T cell cytokine profiles in childhood asthma. Thorax. 2003; 58(4):311-6. [DOI:10.1136/thorax.58.4.311] [PMID] [PMCID]

12. Bossley CJ, Fleming L, Gupta A, Regamey N, Frith J, Oates $\mathrm{T}$, et al. Pediatric severe asthma is characterized by eosinophilia and remodeling without $\mathrm{T}(\mathrm{H}) 2$ cytokines. The Journal of Allergy and Clinical Immunology. 2012; 129(4):974-82. [DOI:10.1016/j.jaci.2012.01.059] [PMID] [PMCID]

13. LEUNG TF, Wong GW. Noninvasive Monitoring of Airway Inflammation in Childhood Asthma. Hong Kong Journal of Paediatrics. 2007; 12:38-41.

14. Mehta AA, Mahajan S. Role of cytokines in pathophysiology of asthma. Iranian Journal of Pharmacology and Therapeutics. 2006; 5(1):1-14.

15. Kabesch M, Schedel M, Carr D, Woitsch B, Fritzsch C, Weiland SK, et al. IL-4/IL-13 pathway genetics strongly influence serum IgE levels and childhood asthma. The Journal of Allergy and Clinical Immunology. 2006; 117(2):269-74. [DOI:10.1016/j.jaci.2005.10.024] [PMID]

16. Koloskova E, Bezrukov L, Marusyk U, Lobanova T, Burenyuk C. Markers of Atopic Reactivity In The Puplis With Severe Bronchial Asthma. Health Sciences. 2016; 3:12-6. [DOI:10.21303/2504-5679.2016.00072]

17. Shahid SK, Kharitonov SA, Wilson NM, Andrew Bush A, Barnes PJ. Increased interleukin-4 and decreased interferon ${ }_{-}$in exhaled breath condensate of children with asthma. American Journal of Respiratory and Critical Care Medicine. 2002; 165:1290-3. [DOI:10.1164/ rccm.2108082] [PMID]

18. Hussein YM, Alzahrani SS, Alharthi AA, Ghonaim MM, Alhazmi AS, Eed EM, et al. Association of serum cytokines levels, interleukin $10-1082 \mathrm{G} / \mathrm{A}$ and interferon-gamma +874T/A polymorphisms with atopic asthma children from Saudi Arabia. Cellular Immunology. 2014; 289(12):21-6. [DOI:10.1016/j.cellimm.2014.03.006] [PMID]

19. Keskin O, Keskin M, Kucukosmanoglu E, Ozkars MY, Gogebakan B, Kul S, et al. Exhaled RANTES and interleukin 4 levels after exercise challenge in children with asthma. Annals of allergy, asthma \& immunology: Official publication of the American College of Allergy, Asthma, \& Immunology. 2012; 109(5):303-8. [DOI:10.1016/j. anai.2012.08.009] [PMID]

20. Al-Daghri NM, Alokail MS, Draz HM, Abd-Alrahman SH, Yakout SM, Clerici M. Th1/Th2 cytokine pattern in Arab children with severe asthma. International Journal of Clinical and Experimental Medicine. 2014; 7(8):2286-91. [PMID] [PMCID]

21. Bush A. Problematic, severe asthma in children: A new concept and how to manage it. Acta Medica Lituanica. 2010; 17(1):51-64. [DOI:10.2478/v10140-010-0007-7]

22. Machura E, Mazur B, Rusek-Zychma M, Barc-Czarnecka M. Cytokine production by peripheral blood $\mathrm{CD} 4+$ and CD8+ T cells in atopic childhood asthma. Clinical \& Developmental Immunology. 2010; 2010:606139. [DOI:10.1155/2010/606139] [PMID] [PMCID]

23. Zagórska W, Grzela K, Kulus M, Sobczyński M, Grzela T. Nitric oxide, IL-6 and IL-13 are increased in the exhaled breath condensates of children with allergic rhinitis. Acta Paediatrica. 2014; 103(4):e148-53. [DOI: 10.1111/ apa.12547]

24. Rosenwasser LJ, Zimmermann N, Hershey GK, Foster PS, Rothenberg ME. Chemokines in asthma: Cooperative interaction between chemokines and IL-13. Journal of Allergy and Clinical Immunology. 2003; 111(2):227-42. [DOI:10.1067/mai.2003.139] [PMID]

25. Fitzpatrick AM, Higgins M, Holguin F, Brown LA, Teague WG. The molecular phenotype of severe asthma in children. The Journal of Allergy and Clinical Immunology. 2010; 125(4):851-7.e18. [DOI:10.1016/j.jaci.2010.01.048] [PMID] [PMCID] 
26. Saha SK, Berry MA, Parker D, Siddiqui S, Morgan A, May R, et al. Increased sputum and bronchial biopsy IL-13 expression in severe asthma. The Journal of Allergy and Clinical Immunology. 2008; 121(3):685-91. [DOI:10.1016/j. jaci.2008.01.005] [PMID] [PMCID]

27. Papathanassiou E, Loukides S, Bakakos P. Severe asthma: Anti-IgE or anti-IL-5. European Clinical Respiratory Journal. 2016; 3(1):31813. [DOI:10.3402/ecrj.v3.31813]

28. Sulaiman I, Lim JC, Soo HL, Stanslas J. Molecularly targeted therapies for asthma: Current development, challenges and potential clinical translation. Pulmonary Pharmacology \& Therapeutics. 2016; 40:52-68. [DOI:10.1016/j. pupt.2016.07.005] [PMID]

29. Anderson WC, Szefler SJ. New and future strategies to improve asthma control in children. The Journal of Allergy and Clinical Immunology. 2015; 136(4):848-59. [DOI:10.1016/j.jaci.2015.07.007]

30. Tateno H, Nakamura H, Minematsu N, Nakajima T, Takahashi $\mathrm{S}$, Nakamura $\mathrm{M}$, et al. Plasma eotaxin level and severity of asthma treated with corticosteroid. Respiratory Medicine. 2004; 98(8):782-90. [DOI:10.1016/j. rmed.2004.01.005] [PMID]

31. Morishima Y, Ano S, Ishii Y, Ohtsuka S, Matsuyama M, Kawaguchi M, et al. Th17-associated cytokines as a therapeutic target for steroid-insensitive asthma. Clinical and Developmental Immunology. 2013. Article ID: 609395. [DOI:10.1155/2013/609395] [PMID] [PMCID]

32. Zeng R, Li C, Li N, Wei L, Cui Y. The role of cytokines and chemokines in severe respiratory syncytial virus infection and subsequent asthma. Cytokine. 2011; 53(1):1-7. [DOI:10.1016/j.cyto.2010.09.011] [PMID]

33. Alyasin S, Karimi MH, Amin R, Babaei M, Darougar S. Interleukin-17 gene expression and serum levels in children with severe asthma. Iranian Journal of Immunology. 2013; 10(3):177-85. [PMID]

34. Chakir J, Shannon J, Molet S, Fukakusa M, Elias J, Laviolette $\mathrm{M}$, et al. Airway remodeling-associated mediators in moderate to severe asthma: Effect of steroids on TGF-beta, IL-11, IL-17, and type I and type III collagen expression. The Journal of Allergy and Clinical Immunology. 2003; 111(6):1293-8. [DOI:10.1067/mai.2003.1557] [PMID]

35. Padrón Morales J, García Solaesa V, Isidoro García M, Hernández Hernández L, García Sánchez A, Hincapié López $\mathrm{G}$, et al. Implications of cytokine genes in allergic asthma. Allergol Immunopathol. 2014; 42(6):603-8. [DOI:10.1016/j.aller.2013.11.006] [PMID]

36. Ghaffari J, Rafiei AR, Ajami A, Mahdavi M, Hoshiar B. Serum interleukins 6 and 8 in mild and severe asthmatic patients, is it difference. Caspian Journal of Internal Medicine. 2011; 2(2):226-8. [PMID] [PMCID]

37. Al-Alawi M, Tidi Hassan T, Chotirmall SH. Transforming growth factor $\mathrm{b}$ and severe asthma: A perfect storm. Res- piratory Medicine. 2014; 108:1409-23. [DOI:10.1016/j. rmed.2014.08.008] [PMID]

38. Raby BA, Van Steen K, Lazarus R, Celedon JC, Silverman EK, Weiss ST. Eotaxin polymorphisms and serum total IgE levels in children with asthma. The Journal of Allergy and Clinical Immunology. 2006; 117(2):298-305. [DOI:10.1016/j.jaci.2005.10.041] [PMID]

39. Chary AV, Hemalatha R, Murali MV, Jayaprakash D, Kumar BD. Association of T-regulatory cells and CD23/CD21 expression with vitamin $D$ in children with asthma. Annals of Allergy, Asthma \& Immunology. 2016; 116(5):447-54. [DOI:10.1016/j.anai.2016.02.018]

40. Brown SD, Baxter KM, Stephenson ST, Esper AM, Brown LAS, Fitzpatrick AM. Airway TGF- $\beta 1$ and oxidant stress in children with severe asthma: Association with airflow limitation. Journal of Allergy and Clinical Immunology. 2012; 129(2):388-396. [DOI:10.1016/j.jaci.2011.11.037]

41. El-Sayed ZA, El-Hakim IZ, El-Kerdani TA, Ghanem HM. Serum transforming growth factor-beta1 in asthmatic children. Egyptian Journal of Pediatric Allergy and Immunology. 2004; 2(1):46-51.

42. Sharma S, Raby BA, Hunninghake GM, Soto-Quiros M, Avila L, Murphy AJ, et al. Variants in TGFB1, dust mite exposure, and disease severity in children with asthma. American Journal of Respiratory and Critical Care Medicine. 2009; 179(5):356-62. [DOI:10.1164/rccm.20080812680C] [PMID] [PMCID]

43. Konradsen JR, Nordlund B, Levanen B, Hedlin G, Linden A. The cytokine interleukin-26 as a biomarker in pediatric asthma. Respiratory Research. 2016; 17:32. [DOI:10.1186/s12931-016-0351-6] [PMID] [PMCID]

44. Kato M, Suzuki K, Yamada $Y$, Maruyama K, Hayashi $Y$, Mochizuki $\mathrm{H}$. Virus detection and cytokine profile in relation to age among acute exacerbations of childhood asthma. Allergology International. 2015; 64:S64-S70. [DOI:10.1016/j.alit.2015.06.008]

45. Machura E, Szczepanska M, Mazur B, Chrobak E, Ziora K, Ziora D, et al. Selected CC and CXC chemokines in children with atopic asthma. Postepy Dermatologii I Alergologii. 2016; 33(2):96-101. [DOI:10.5114/ada.2016.59150]

46. Parulekar AD, Diamant Z, Hanania NA. Role of T2 inflammation biomarkers in severe asthma. Current Opinion in Pulmonary Medicine. 2016; 22(1):59-68. [DOI:10.1097/ MCP.0000000000000231] [PMID]

47. Grzela K, Litwiniuk M, Krejner A, Zagorska W, Grzela T. Increased angiogenic factors in exhaled breath condensate of children with severe asthma - New markers of disease progression. Respiratory Medicine. 2016; 118:119-21. [DOI:10.1016/j.rmed.2016.08.005] [PMID]

48. Leung TF, Wong GW, Ko FW, Li CY, Yung E, Lam CW, et al. Analysis of growth factors and inflammatory cytokines in exhaled breath condensate from asthmatic children. 
International Archives of Allergy and Immunology. 2005; 137(1):66-72. [DOI:10.1159/000085106] [PMID]

49. Lukacs NW. Role of chemokines in the pathogenesis of asthma. Nature Reviews Immunology. 2001; 1(2):108-16. [DOI:10.1038/35100503] [PMID]

50. Leung TF, Wong CK, Lam CW, Li AM, Ip WK, Wong GW, et al. Plasma TARC concentration may be a useful marker for asthmatic exacerbation in children. The European Respiratory Journal. 2003; 21(4):616-20. [DOI:10.1183/0903 1936.03.00083303] [PMID]

51. Hartl D, Griese M, Nicolai T, Zissel G, Prell C, Konstantopoulos $\mathrm{N}$, et al. Pulmonary chemokines and their receptors differentiate children with asthma and chronic cough. The Journal of Allergy and Clinical Immunology. 2005; 115(4):728-36. [DOI:10.1016/j.jaci.2004.11.049] [PMID]

52. Saad-El-Din Bessa S, Abo El-Magd GH, Mabrouk MM. Serum chemokines RANTES and monocyte chemoattractant protein-1 in Egyptian patients with atopic asthma: Relationship to disease severity. Archives of Medical Research. 2012; 43(1):36-41. [DOI:10.1016/j.arce med.2012.01.009] [PMID]

53. Huang $\mathrm{H}$, Nie W, Zang $\mathrm{Y}$, Chen J, Xiu Q. Association between CC motif chemokine ligand 5 (CCL5) polymorphisms and asthma risk: an updated meta-analysis. Journal of Investigational Allergology \& Clinical Immunology. 2015; 25(1):26-33. [PMID]

54. El-Gamal Y, El-Awady HM, El-Halim AA, Abd-Allah E. Increased expression of T-cell-surface CXCR4 in asthmatic children. Egyptian Journal of Pediatric Allergy and Immunology. 2003; 1(2):80-5.

55. Carr TF, Berdnikovs S, Simon H, Bochner BS, Rosenwasser LJ. Eosinophilic bioactivities in severe asthma. World Allergy Organization Journal. 2016; 9:21. [DOI:10.1186/ s40413-016-0112-5]

56. El-Gamal YM, Heshmat NM, Awwad KS, Ezzat MHM, Abd Al-Aziz MM, El-Gabbas ZM. Monocyte Chemotactic Protein-4 (MCP-4; CCL-13) and the CC chemokine Receptor 3 (CCR3) in Sputum of Asthmatic Children. The Journal of Allergy \& Clinical Immunology. 2007; 119(Suppl 1):S72. [DOI:10.1016/j.jaci.2006.11.304]

57. Eder W, Klimecki W, Yu L, von Mutius E, Riedler J, BraunFahrlander $\mathrm{C}$, et al. Toll-like receptor 2 as a major gene for asthma in children of European farmers. The Journal of Allergy and Clinical Immunology. 2004; 113(3):482-8. [DOI:10.1016/j.jaci.2003.12.374] [PMID]

58. Saglani S, Lloyd CM. Eosinophils in the pathogenesis of paediatric severe asthma. Current Opinion in Allergy and Clinical Immunology. 2014; 14(2):143-8. [DOI:10.1097/ ACl.0000000000000045] [PMID]

59. Barreto M, Zambardi R, Villa MP. Exhaled nitric oxide and other exhaled biomarkers in bronchial challenge with exercise in asthmatic children: Current knowl- edge. Paediatric Respiratory reviews. 2015; 16(1):68-74 [DOI:10.1016/j.prrv.2013.11.006] [PMID]

60. Ullmann N, Bossley CJ, Fleming L, Silvestri M, Bush A, Saglani S. Blood eosinophil counts rarely reflect airway eosinophilia in children with severe asthma. Allergy. 2013; 68(3):402-6. [DOI:10.1111/all.12101] [PMID]

61. Katoa M, Yamadaa Y, Maruyamab K, Hayashic K. Serum eosinophil cationic protein and 27 cytokines/chemokines in acute exacerbation of childhood asthma. International Archives of Allergy and Immunology. 2010; 152:62-6. [DOI:10.1159/000312127] [PMID]

62. Bossley C, Suri R. An update on paediatric severe asthma. Current Allergy \& Clinical Immunology. 2013; 26(3):11420.

63. Brehm JM, Schuemann B, Fuhlbrigge AL, Hollis BW, Strunk $\mathrm{RC}$, Zeiger RS, et al. Serum vitamin D levels and severe asthma exacerbations in the Childhood Asthma Management Program study. The Journal of Allergy and Clinical Immunology. 2010; 126(1):52-8.e5. [DOI:10.1016/j. jaci.2010.03.043] [PMID] [PMCID]

64. Majak P, Olszowiec-Chlebna M, Smejda K, Stelmach I. Vitamin $D$ supplementation in children may prevent asthma exacerbation triggered by acute respiratory infection. The Journal of Allergy and Clinical Immunology. 2011 127(5):1294-6. [DOI:10.1016/j.jaci.2010.12.016] [PMID]

65. Hamzaoui A, Ammar J, Hamzaoui K. Regulatory T cells in induced sputum of asthmatic children: Association with inflammatory cytokines. Multidisciplinary Respiratory Medicine. 2010; 5(1):22-30. [DOI:10.1186/2049-6958-51-22] [PMID] [PMCID]

66. Hassannia H, Abediankenari S, Ghaffari J. FOXP3 and TGF- $\beta$ Gene Polymorphisms in Allergic Rhinitis. Iranian Journal of Immunology. 2011; 8(4):218-25. [PMID]

67. Papaioannou Al, Spathis A, Kostikas K, Karakitsos P, Papiris $\mathrm{S}$, Rossios $\mathrm{C}$. The role of endosomal toll-like receptors in asthma. European Journal of Pharmacology. 2017 808:14-20. [DOI:10.1016/j.ejphar.2016.09.033] [PMID]

68. Zakeri A, Yazdi FG. Toll-like receptor-mediated involvement of innate immune cells in asthma disease. Biochimica et Biophysica Acta. 2017; 1861(1 Pt A):3270-7. [DOI:10.1016/j.bbagen.2016.08.009] [PMID]

69. Katsaounou P, Asimakos A, Barnes PJ. Non invasive assessment of severe asthma. Pneumon. 2011; 24(4):430.

70. Vijverberg SJ, Hilvering B, Raaijmakers JA, Lammers JW, Maitland-van der Zee AH, Koenderman L. Clinical utility of asthma biomarkers: From bench to bedside. Biologics: Targets \& Therapy. 2013; 7:199-210. [PMID] [PMCID]

71. Alessandra Chiappori A, Laura De Ferrari LD, Chiara Folli C, Pierluigi Mauri P, Riccio AM, Canonica GW. Biomarkers and severe asthma: A critical appraisal. Clinical and Molecular Allergy. 2015; 13(20). [PMID] [PMCID] 
72. Kaza V, Bandi V, Guntupalli K. Acute severe asthma: Recent advances. Current Opinion in Pulmonary Medicine. 2007; 13:1-7. [DOI:10.1097/MCP.0b013e328011a91c]

73. Matsunaga K, Yanagisawa S, Ichikawa T, Ueshima K, Keiichirou Akamatsu K, Tsunahiko Hirano T, et al. Airway cytokine expression measured by means of protein array in exhaled breath condensate: Correlation with physiologic properties in athmatic patients. The Journal of Allergy and Clinical Immunology. 2006; 118. [DOI:10.1016/j. jaci.2006.04.020]

74. Korevaar DA, Westerhof GA, Wang J, Cohen JF, Spijker R, Sterk PJ, et al. Diagnostic accuracy of minimally invasive markers for detection of airway eosinophilia in asthma: A systematic review and meta-analysis. The Lancet Respiratory Medicine. 2015; 3(4):290-300. [DOI:10.1016/S22132600(15)00050-8]

75. Meyer N, Nuss SJ, Rothe T, Siebenhuner A, Akdis CA, Menz G. Differential serum protein markers and the clinical severity of asthma. Journal of Asthma and Allergy. 2014; 7:67-75. [DOI:10.2147/JAA.S53920] [PMID] [PMCID] 
This Page Intentionally Left Blank 